\title{
PENGARUH FASILITAS LABORATORIUM KOMPUTER, PENGUASAAN KOMPUTER, AKUNTANSI DASAR, DAN EFIKASI DIRI TERHADAP HASIL BELAJAR KOMPUTER AKUNTANSI ACCURATE SISWA KELAS XI AKUNTANSI SMK NEGERI 3 BANGKALAN
}

\author{
Nurod Osianto ${ }^{1}$, Hetty Purnamasari ${ }^{2}$, Soubar Isman ${ }^{3}$ \\ 1,2,3 Universitas Dr. Soetomo \\ Email: ${ }^{1}$ nurod.osianto@gmail.com
}

\begin{abstract}
Abstrak
Pembelajaran dalam kurikulum 2013 menitikberatkan pada proses bukan hanya hasil, dalam prosesnya ada 4 hal yang diperoleh siswa dari setiap mata pelajaran, yaitu sikap, keterampilan, pengetahuan dan perilaku. Melalui keempat aspek tersebut diharapkan siswa tidak hanya pandai tetapi juga memiliki keterampilan yang nanti pasti akan dibutuhkan di masa mendatang. Tujuan penelitian ini antara lain untuk membuktikan: 1) fasilitas laboratorium komputer kelas XI Akuntansi di SMKN 3 Bangkalan, 2) penguasaan komputer siswa kelas XI Akuntansi di SMKN 3 Bangkalan, 3) penguasaan akuntasi siswa kelas XI Akuntansi di SMKN 3 Bangkalan, 4) efikasi diri siswa kelas XI Akuntansi di SMKN 3 Bangkalan, dan 5) pengaruh penguasaan komputer dan efikasi diri terhadap hasil belajar komputer akuntansi accurate siswa kelas XI Akuntansi di SMK Negeri 3 Bangkalan. Peneliti menggunakan pendekatan kualitatif karena semua data penelitian berbentuk kuantitatif. Penelitian mengumpulkan berbagai data variabel penelitian menggunakan instrumen yan telah dinyatakan valid dan variabel. Selanjutnya data yang diperoleh, dianalisis menggunakan statistik dengan rumus korelasi product moment dan korelasi ganda. Berdasarkan hasil analisis data, diperoleh kesimpulan, antara lain: 1) fasilitas laboratorium komputer siswa kelas XI Akuntansi di SMKN 3 Bangkalan cukup baik, 2) penguasaan komputer siswa kelas XI Akuntansi di SMKN 3 Bangkalan cukup baik, 3) penguasaan akuntasi siswa kelas XI Akuntasi di SMK 3 Bangkalan cukup baik, 4) efikasi diri siswa kelas XI SMKN 3 Bangkalan cukup baik, dan 5) pengaruh Penguasaan Komputer dan Efikasi Diri terhadap Hasil Belajar Komputer Akuntansi Accurate Siswa Kelas XI Akuntansi di SMK Negeri 3 Bangkalan

Keyword: Laboratorium Komputer, Penguasaan Komputer, Akuntansi Dasar, Efikasi Diri, Hasil Belajar

\section{Abstract}

Learning in the 2013 curriculum focuses on the process, not just results, in the process there are 4 things that students get from each subject, namely attitudes, skills, knowledge and behavior. Through these four aspects, it is hoped that students will not only be smart but also have skills that will definitely be needed in the future. In addition, in the 2013 curriculum, education in Indonesia has also begun to utilize technology which is considered more effective and efficient than using manual systems. The objectives of this study were to prove: 1) computer laboratory facilities for class XI Accounting at SMKN 3 Bangkalan, 2) computer mastery of class XI accounting students at SMKN 3 Bangkalan, 3) accounting mastery of class XI accounting students at SMKN 3 Bangkalan, 4) efficacy students in class XI Accounting at SMKN 3 Bangkalan, and 5) the influence of computer mastery and self-efficacy on the learning outcomes of accurate accounting for class XI accounting students at SMK Negeri 3 Bangkalan. Researchers used a qualitative approach because all research data were quantitative in form. The study collected various data on research variables using instruments that have been declared valid and variable. Furthermore, the data obtained were analyzed using statistics with the product moment correlation formula and multiple correlation. Based on the results of data analysis, the following conclusions were obtained, among others: 1) the computer laboratory facilities of the XI accounting class students at SMKN 3 Bangkalan were quite good, 2) the computer mastery of the XI accounting class students at SMKN 3 Bangkalan was quite good, 3) accounting mastery of the XI class students of Accounting at SMK 3 Bangkalan is quite good, 4) self-efficacy of class XI students of SMKN 3 Bangkalan is quite good, and 5) the influence of Computer Mastery and Self-Efficacy on Learning Outcomes of Accurate Accounting for Class XI Accounting Students at SMK Negeri 3 Bangkalan.
\end{abstract}

Keywords: Computer Laboratory, Computer Mastery, Basic Accounting, Self-Efficacy, Learning Outcomes

\section{PENDAHULUAN}

Pembelajaran dalam kurikulum 2013 menitikberatkan pada proses bukan hanya hasil, dalam prosesnya ada 4 hal yang diperoleh siswa dari setiap mata pelajaran, yaitu sikap, keterampilan, 
pengetahuan dan perilaku. Melalui keempat aspek tersebut diharapkan siswa tidak hanya pandai tetapi juga memiliki keterampilan yang nanti pasti akan dibutuhkan di masa mendatang. Selain itu, dalam kurikulum 2013 pendidikan di Indonesia juga sudah mulai memanfaatkan teknologi yang dinilai lebih efektif dan efisien daripada menggunakan sistem manual. Hamzah B.Uno dan Nina Lamatenggo (dalam Zulkarnaen, 2014:5) mendefinisikan teknologi informasi sebagai teknologi yang dipakai untuk mengolah, memroses, menyusun, menyimpan, memanipulasi data menggunakan banyak cara untuk mendapatkan informasi yang dapat dipertanggungjawabkan. Mata pelajaran komputer akuntansi ini memang penting diajarkan di SMK, karena ketika mereka lulus nanti akan berguna di dunia kerja. Software komputer akuntansi yang baru-baru ini digunakan di Sekolah Menengah Kejuruan adalah Accurate. Software akuntansi keuangan yang dibuat untuk membantu perusahaan dalam pengoalahan data keuangan. Program accurate sebagai software akuntansi ini mulai dikenalkan pada 26 Oktober 1998 oleh pendirinya yaitu Cipta Piranti Sejahtera atau dikenal dengan CPSSoft sebagai pengemban software (Yuliana, 2013:237).

Aplikasi ini memudahkan pengguna nya untuk melakukan kegiatan pencatatan akuntansi. Maka dari itu hasil belajar komputer akuntansi Accurate ini harus diperhatikan, agar siswa memeroleh nilai yang bagus maka peserta harus benar-benar memahami materi sekaligus praktek dalam studi komputer akuntansi accurate ini. Hasil belajar accurate dapat ditunjukkan dengan hasil sebagai tolak ukur tingkat kemampuan siswa dalam menguasai accurate. Apabila nilai anak tinggi maka proses belajar dapat dikatakan berhasil, namun apabila nilai siswa rendah maka proses belajar yang terjadi kurang maksimal atau ada beberapa masalah yang mempengaruhi proses pembelajaran. Hasil yang diharapkan dalam pembelajaran komputer akuntansi accurate adalah siswa dapat mengikuti proses belajar dan mendapatkan nilai yang baik. Tetapi fakta dilapangan tidak selalu sesuai dengan harapan. Berdasarkan hasil identifikasi diperoleh informasi bahwa tidak semua siswa menjalankan proses dengan benar sehingga hasilnya juga buruk. Pengamatan pada kelas XI AKuntansi di SMK Negeri 3 Bangkalan yang mengikuti pembelajaran komputer akuntansi accurate menunjukkan bahwa beberapa siswa masih bingung mengoperasikan program accurate sehingga hasil belajar mereka belum maksimal. Hasil belajar accurate yang dicapai siswa berhubungan dengan hal yang mempengaruhi. Output siswa ini dipengaruhi oleh faktor siswa dan faktor pembelajaran di sekolah. Faktor pada saat pembelajaran ini bisa dilihat dari segi fasilitas sekolah yang ada. SMK Negeri 3 Bangkalan merupakan sekolah yang cukup baik diwilayah Bangkalan yang memiliki ruangan komputer dan dipakai ketika mata pelajaran accurate. Namun banyaknya computer yang ada sedikit sehingga siswa biasanya membawa laptop sendiri untuk bisa belajar bersama. Tetapi fasilitas didalam laboratorium tersebut sudah cukup baik yaitu adanya LCD, pendingin ruangan, CCTV dan rak sepatu didepan laboratorium.

"Jika guru dapat menampilkan gaya mengajar secara efisien dan efektif maka dapat mencapai tingkat keberhasilan yang diinginkan, namun sebaliknya jika seorang guru tersebut memaksakan kehendaknya dan bersifat emosional dalam belajar maka siswa akan tertekan dan akan membuat hasil belajar siswa tersebut rendah" (Deswita, 2013:2). "Pencapaian prestasi belajar Akuntansi yang optimal dalam proses belajar siswa dapat dipengaruhi oleh banyak faktor. Hal inilah yang mungkin menjadi penyebab kurangnya daya serap siswa dalam mencapai prestasi belajar. Dalam proses pembelajaran diperlukan adanya kemandirian belajar agar tercapai tujuan pembelajaran yang baik" (Aini dan Taman, 2012:50). "Anggapan yang berkembang di kalangan siswa pada umumnya bahwa mata pelajaran akuntansi sulit karena dalam mempelajari akuntansi dibutuhkan konsentrasi, ketelitian dan keterampilan yang tinggi. Mata pelajaran akuntansi tidak hanya berisi konsep-konsep teori saja akan tetapi berisi materi yang membutuhkan suatu penalaran untuk menyelesaikannya" (Novalinda dkk, 2017:115).

Berdasarkan hasil pengamatan peneliti karena jumlah komputer yang ada di laboratorium tidak sesuai dengan jumlah siswa maka beberapa murid hanya duduk diam selama pelajaran. Kemudian ada beberapa siswa yang bergabung dalam satu komputer. Hal yang berhubungan dengan kegiatan pembelajaran adalah kecerdasan, hal pribadi, fasilitas dan media yang dipakai dalam kegiatan belajar. Kecerdasan meliputi penguasaan akutansi dasar, penguasaan dasar komputer, dan nilai matematika. Faktor pribadi dilihat dari efikasi diri. Media pengajaran dilihat dari fasilitas laboratorium komputer yang dimiliki sekolah. Faktor yang berasal dari diri sendiri dan berpengaruh terhadap pembelajaran accurate ialah penguasaan siswa dalam mengoperasikan komputer. Penguasaan dalam mengoperasikan komputer ini meliputi penguasaan anak untuk mengoperasikan komputer ditambah dengan kecerdasan dari lahir bisa juga melalui pembelajaran melalui pengalaman. 
Tujuan penelitian untuk membuktikan adanya: 1) Fasilitas laboratorium komputer siswa kelas XI Akuntansi di SMKN 3 Bangkalan, 2) Penguasaan komputer siswa kelas XI Akuntansi di SMKN 3 Bangkalan, 3) Penguasaan akuntasi siswa kelas XI Akuntasi di SMK 3 Bangkalan, 4) Efikasi diri siswa kelas XI SMKN 3 Bangkalan, dan 5) Pengaruh Penguasaan Komputer dan Efikasi Diri terhadap Hasil Belajar Komputer Akuntansi Accurate Siswa Kelas XI Akuntansi di SMK Negeri 3 Bangkalan.

Menurut Decaprio (2013:16) laboratorium yakni tempat kelompok orang yang melakukan berbagai kegiatan penelitian, pengamatan, pelatihan, dan pengujian ilmiah sebagai pendekatan antara teori dan praktik dari beberapa disiplin ilmu. Bisa dikatakan laboratorium yakni tempat yang dilengkapi fasilitas dan kebutuhan pembelajaran yang digunakan oleh kumpulan siswa untuk melakukan percobaan dan penyelidikan kegiatan ilmiah yang dikelola oleh guru.

Selanjutnya selain faktor internal yang dimiliki siswa, prestasi belajar Komputer Akuntansi diduga dipengaruhi oleh faktor eksternal siswa yaitu fasilitas laboratorium akuntansi. Menurut Purwanto (2010:107) sarana dan fasilitas termasuk kedalam instrumental input atau faktor-faktor yang sengaja dirancang yang mempengaruhi proses dan hasil belajar. Mariyana (2013:149) mengemukakan bahwa fasilitas yang lengkap dan representatif memberikan kesempatan anak beraktivitas dan bereksplorasi serta dukungan fasilitas yang lengkap dan memadai memberikan nilai yang lebih bermakna ketika anak belajar. Laboratorium akuntansi merupakan fasilitas yang dimiliki sekolah dalam menunjang mata pelajaran Komputer Akuntansi. Tersedianya fasilitas yang mendukung akan memberikan kesempatan luas bagi siswa untuk meningkatkan prestasi belajarnya. Indikator-indikator dari fasilitas laboratorium komputer antara lain: 1) ruangan komputer, 2) penerangan memadai, 3) pendingin ruangan, 4) buku penunjang komputer, 5) perangkat komputer, dan 6) kebersihan (Gie, 2004:46).

Menurut Blissmer (dalam Susanto, 2009:2) komputer adalah elektronik yang dapat melaksanakan beberapa tugas seperti menerima input, memproses sesuai dengan program, menyimpan perintah dan hasil pengolahan, lalu menyediakan output berbentuk informasi. Penguasaan merupakan kemampuan nyata dari sebuah pengetahuan dan keahlian yang dimiliki seseorang. Dengan pemahaman yang baik, maka informasi yang dihasilkan juga baik. Penguasaan komputer dapat diartikan kemampuan dalam menggunakan komputer, operating system, penanganan file dan perangkat keras, penyimpanan data dan penggunaan keyboard. Untuk terampil mengoperasikan komputer dapat mempelajari modul penggunaan dan secara rutin berlatih untuk mengoperasikannya.

Pada awal perkembangannya aplikasi komputer yang pertama adalah pengolahan data akuntansi atau lebih dikenal dengan data processing. Aplikasi tersebut lalu diikuti oleh empat aplikasi lain, yaitu sistem informasi manajemen, sistem pendukung keputusan, kantor virtual, dan sistem berbasis pengetahuan. Kelima aplikasi ini membentuk sistem informasi berbasis komputer. Informasi adalah salah satu jenis sumber daya yang tersedia bagi manajer. Informasi dapat dikelola seperti halnya sumber daya yang lain seperti tanah, modal, sumber daya manusia, mesin dan lain-lain. Informasi dihasilkan melalui proses pengolahan data. Komputer telah digunakan sebagai pengolah data untuk menghasilkan informasi. Output informasi yang berasal dari komputer digunakan oleh manajer, nonmanajer, serta orang-orang dan organisasi-organisasi dalam lingkungan perusahaan, dan dalam semua bidang fungsional. Manajer memerlukan keahlian dalam komunikasi dan pemecahan masalah agar berhasil dalam menjalankan peran dan fungsinya. Saat ini sudah jarang perusahaan yang menggunakan sistem informasi akuntansi berbasis teknologi manual. Sebagian besar perusahaan-perusahaan, terutama perusahaan skala menengah dan atas sudah menggunakan sistem informasi akuntansi berbasis teknologi komputer. Agar dapat menggunakan, mengevaluasi, dan mengembangkan sistem informasi akuntansi yang modern (berbasis komputer computer based accounting information system) dibutuhkan sumber daya manusia yang memahami komputer.

Perkembangan teknologi informasi telah membawa dampak dalam kehidupan masyarakat. Sejak diketemukannya komputer pada tahun 1955, peradaban dunia telah memasuki era informasi. Teknologi informasi dengan komputer sebagai motor penggeraknya telah mengubah segalanya. Pemrosesan informasi berbasis komputer mulai dikenal orang dan hingga saat ini sudah banyak software yang dapat digunakan orang sebagai alat pengolah data untuk menghasilkan informasi. Dibidang akuntansi, sistem pemrosesan informasi akuntansi berbasis komputer banyak ditawarkan dengan tujuan untuk memberikan kemudahan bagi para akuntan untuk menghasilkan informasi yang dapat dipercaya, relevan, tepat waktu, lengkap, dapat dipahami, dan teruji (Maharsi, 2000:128). Perubahan lingkungan ini juga menuntut akuntansi manajemen sebagai suatu sistem informasi untuk menyediakan informasi yang dapat dipercaya, relevan, tepat waktu, lengkap, dapat dipahami, dan teruji dalam rangka pengambilan keputusan manajemen. Sistem informasi akuntansi manajemen adalah sistem informasi yang memproses input sehingga menghasilkan output untuk mencapai tujuan khusus manajemen. Proses adalah inti dari sistem informasi akuntansi manajemen. Proses dapat dijelaskan oleh aktivitas seperti pengumpulan, (collecting), 
pengukuran (measuring), penyimpanan (storing), analisis (analysis), pelaporan (reporting), dan pengelolaan (managing) informasi. Output yang dihasilkan dapat berupa laporan khusus, biaya produksi, biaya pelanggan, anggaran, laporan kinerja, bahkan komunikasi personal.

Menurut Bandura (dalam Feist dan Feist, 2014:212) efikasi diri merupakan keyakinan seseorang terhadap kemampuannya sendiri untuk mengelola dan melaksanakan beberapa hal sesuai dengan kemampuannya sendiri dan dipengaruhi oleh lingkungan sekitar. Efikasi diri disebut sebuah kepribadian yang krucial, artinya seseorang tersebut yakin dan percaya diri terhadap kemampuan dirinya sendiri untuk melakukan hal yang bertujuan pada hasil yang diinginkan.

Efikasi diri menurut Alwisol, (2005) dapat diperoleh, diubah, ditingkatkan atau diturunkan, melalui salah satu atau kombinasi empat sumber, yakni pengalaman menguasai sesuatu prestasi (performance accomplishment), pengalaman vikarius (vicarious experiences), persuasi sosial (social persuation) dan pembangkitan emosi (emotional/physiological states). Pengalaman performansi adalah prestasi yang pernah dicapai pada masa yang telah lalu. Pengalaman vikarius diperoleh melalui model sosial. Persuasi sosial adalah rasa percaya kepada pemberi persuasi, dan sifat realistik dari apa yang dipersuasikan Efikasi diri diduga akan mempengaruhi self regulated learning. Orang yang memiliki efikasi diri yang tinggi akan memiliki keyakinan mengenai kemampuannya dalam mengorganisasi dan menyelesaikan suatu tugas yang diperlukan untuk mencapai hasil tertentu dalam berbagai bentuk dan tingkat kesulitan. Hal ini berdampak self regulated learning juga akan tinggi. Ia akan mampu mengelola mengelola secara efektif pengalaman belajarnya sendiri di dalam berbagai cara sehingga mencapai hasil belajar yang optimal. Efikasi diri yang rendah akan sangat mempengaruhi seseorang dalam menyelesaikan tugasnya untuk mencapai hasil tertentu. Hal ini dapat dikaitkan dengan kurangnya informasi tentang kemampuan para siswa untuk yakin pada dirinya sendiri dalam mengerjakan tugas yang diberikan kepada mereka.

Hasil belajar accurate merupakan ketrampilan siswa dalam proses belajar yang dilihat dari perkembangan dari aspek kognitif, afektif dan psikomotorik yang tujuan akhirnya mampu memasukan transaksi dan membuat laporan keuangan menggunakan program accurate yang kemudian ditunjukkan dengan nilai akhir berupa penugasan atau tes. Hasil belajar tampak terjadinya perubahan tingkah laku pada diri siswa yang dapat diamati dan diukur melalui perubahan sikap dan keterampilan. Perubahan tersebut dapat diartikan terjadinya peningkatan dan pengembangan yang lebih baik dibandingkan dengan sebelumnya (Wahjudi, 2015: 3-4). Hasil akhir dari kegiatan pembelajaran adalah kompetensi baru atau pengembangan kompetensi dari sebelumnya. Siswa tidak hanya dituntut untuk tahu tetapi juga mampu mengaplikasikan pengetahuan yang mereka pelajari dalam kehidupan sehari-hari. Ketika tidak terjadi perubahan yang signifikan atau tidak ada perubahan sama sekali maka rancangan dan desain pembelajaran yang dibuat oleh guru perlu dipertanyakan dan dievaluasi. Karena pada sesungguhnya tujuan pembelajaran merupakan hasil yang diharapakan mampu dicapai oleh siswa setelah mengikuti kegiatan pembelajaran. Secara umum tujuan pembelajaran adalah sejumlah hasil belajar yang menunjukkan bahwa siswa telah melakukan aktifitas belajar yang meliputi pengetahuan, keterampilan, dan sikap (Siagian, 2012:5)

\section{METODE}

Jenis penelitian yang dipakai yakni penelitian kuantitatif. Penelitian kuantitatif ialah penelitian angka dan teknik analisis dengan statistik. Metode penelitian kuantitatif disebut sebagai metode tradisional, karena telah lama diterapkan sebagai metode penelitian dan banyak yang menggunakan metode tersebut (Sugiyono, 2017:13). Variabel bebas dalam penelitian ini fasilitas laboratorium komputer (X1), nilai matematika (X2), penguasaan komputer (X3), penguasaan akuntansi dasar (X4) dan efikasi diri (X5) sedangkan variabel terikat (Y) adalah hasil belajar accurate.

Populasi dari penelitian ini adalah siswa yang dijadikan obyek penelitian. Populasi penelitian ini adalah siswa-siswi Kelas XI Akuntansi di SMK Negeri 3 Bangkalan yang berjumlah 64 siswa dimana masing-masing kelas terdiri dari 32 siswa. kemudian dari penentuan populasi tersebut, peneliti memilih sampel yang representatif untuk diteliti. Sampel adalah bagian dari jumlah karakteristik yang dimiliki oleh populasi tersebut (Sugiyono, 2014:81). Probably sampling adalah teknik pengambilan sampel yang memberikan peluang yang sama bagi setiap unsur (anggota) populasi untuk dipilih menjadi anggota sampel (Sugiyono, 2014:82). Dikatakan simple random sampling karena pengambilan anggota sampel dari populasi dilakukan secara acak tanpa memperhatikan strata yang ada dalam populasi itu (Sugiyono, 2014:82). Sehubungan dengan jumlah populasi yang tidak banyak maka peneliti memilih teknik sampel jenuh untuk menentukan populasi dalam penelitian ini. Instrumen yang digunakan untuk memperoleh 
data penelitian tentang fasilitas laboratorium komputer, penguasaan komputer, penguasaan akuntansi dasar, dan efikasi diri menggunakan instrumen lembar isian angket. Sedangkan untuk memperoleh data penelitian tentang hasil belajar komputer accurate akuntansi menggunakan instrumen tes. Untuk menjawab rumusan masalah $1,2,3$, dan 4 , peneliti menggunakan rumus $t$-test dan untuk menjawab rumusan yang kelima dimana dua variabel bebas secara bersamaan mempengaruhi satu variabel tetap menggunakan rumus korelasi dan korelasi ganda.

\section{HASIL}

Peneliti melakukan analisis data fasilitas laboratorium komputer dengan menggunakan rumus $t$ test. Data uji t dengan satu sampel kemudian dibandingkan dengan nilai t pada tabel dengan taraf signifikan 5\% dan jumlah sampel sebanyak 32 orang. berdasakan patokan perhitungan di atas, maka dinyatakan bahwa thitung (2.108) lebih besar dari pada t tabel (1.697) sehingga dapat disimpulkan bahwa fasilitas lab. komputer siswa kelas XI Akuntansi di SMKN 3 Bangkalan cukup baik. Kemudian peneliti juga melakukan analisis terhadap data penguasaan komputer siswa. Data uji t dengan satu sampel kemudian dibandingkan dengan nilai t pada tabel dengan taraf signifikan 5\% dan jumlah sampel sebanyak 32 orang. Berdasakan patokan perhitungan di atas, maka dinyatakan bahwa t hitung (2.0104) lebih besar dari pada t tabel (1.697) sehingga dapat disimpulkan bahwa Penguasaan komputer siswa kelas XI Akuntansi di SMKN 3 Bangkalan cukup baik. Analisis data juga dilakukan terhadap data penguasaan akunatnsi dasar siswa. Data uji t dengan satu sampel kemudian dibandingkan dengan nilai t pada tabel dengan taraf signifikan 5\% dan jumlah sampel sebanyak 32 orang. Berdasakan patokan perhitungan di atas, maka dinyatakan bahwa $t$ hitung (2.185) lebih besar dari pada t tabel (1.697) sehingga dapat disimpulkan bahwa Penguasaan akuntansi dasar siswa kelas XI Akuntansi di SMKN 3 Bangkalan cukup baik. Analisis uji t berikutnya dilakukan terhadap data efikasi diri siswa. Data uji t dengan satu sampel kemudian dibandingkan dengan nilai t pada tabel dengan taraf signifikan 5\% dan jumlah sampel sebanyak 32 orang. berdasakan patokan perhitungan di atas, maka dinyatakan bahwa thitung (1.845) lebih besar dari pada t tabel (1.697) sehingga dapat disimpulkan bahwa efikasi diri siswa kelas XI Akuntansi di SMKN 3 Bangkalan cukup baik.

Analisis data selanjutnya menggunakan rumus korelasi product momemnt terhadap data penguasaan komputer, efikasi diri, dan hasil belajar siswa. Nilai $r$ hitung kemudian dibandingkan dengan distribusi nilai r pada tabel untuk jumlah sampel 32 orang dan taraf signifikan 5\%. Jika nilai $r$ hitung lebih besar dari pada nilai r pada tabel maka dapat dinyatakan bahwa hipotesis diterima. Mengacu pada patokan analisis statistik di atas menggunakan rumus korelasi product moment, maka dapat disimpulkan bahwa nilai $r$ hitung (4.429) lebih besar dari pada nilai $r$ pada tabel (0.349). dengan demikian dapat dikatakan bahwa terdapat pengaruh yang signifikan antara penguasaan komputer dan efikasi diri terhadap hasil belajar komputer akuntansi accurate siswa kelas XI Akuntansi di SMK Negeri 3 Bangkalan.

\section{PEMBAHASAN}

Pada saat ini semua sistem kerja di semua bidang dikontrol oleh komputer. Ketersediaan fasilitas komputer dan kemampuan siswa dalam mengoperasikan komputer akan memiliki banyak manfaat dalam mendukung kesuksesan prestasi belajaranya. Komputer memudahkan pekerjaan siswa dalam segala bidang termasuk pembelajaran. siswa hanya melakukan input data yang tepat agar dapat diolah menjadi data yang bermanfaat. Menurut Blissmer (dalam Susanto, 2009:2) komputer adalah elektronik yang dapat melaksanakan beberapa tugas seperti menerima input, memproses sesuai dengan program, menyimpan perintah dan hasil pengolahan, lalu menyediakan output berbentuk informasi. Penguasaaan komputer bagi siswa jurusan akuntansi menjadi wajib. Segala pengelolaan data di dunia bisnis maupun dalam proses pembelajaran sudah dapat dilakukan dengan memanfaatkan aplikasi yang ada dalam komputer. Penguasaan komputer sangat mempengaruhi proses dan hasil belajar siswa kelas XI Akuntansi SMK Negeri 3 Bangkalan. Sistem komputerasi dalam pembukuan dan analisa keuangan semakin mempercepat proses akuntansi. Dibidang akuntansi, sistem pemrosesan informasi akuntansi berbasis komputer banyak ditawarkan dengan tujuan untuk memberikan kemudahan bagi para akuntan untuk menghasilkan informasi yang dapat dipercaya, relevan, tepat waktu, lengkap, dapat dipahami, dan teruji (Maharsi, 2000:128). Data keuangan yang diolah menggunakan aplikasi dalam komputer sangat cepat, lengkap, dan akurat. hal tersebut yang harus dipelajari oleh siswa jurusan akuntansi. Semakin terampil dalam mengoperasikan komputer maka semakin terampil pula siswa melakukan proses akuntan.

Namun kemampuan intelektual bukan satu-satu yang mampu kesuksesan belajar siswa kelas XI Akuntansi SMK Negeri 3 Bangkalan. kemampuan psikologi siswa dalam mengelola pikiran juga menjadi faktor penting yang dapat mempengaruhi proses dan hasil belajar siswa. kemampuan intelektual yang 
memadai tidak dapat diaplikasikan jika siswa tidak percaya terhadap kemampuan yang dimiliki. Menurut Bandura (dalam Feist dan Feist, 2014:212) efikasi diri merupakan keyakinan seseorang terhadap kemampuannya sendiri untuk mengelola dan melaksanakan beberapa hal sesuai dengan kemampuannya sendiri dan dipengaruhi oleh lingkungan sekitar. Keyakinan terhadap kemampuan diri atau percaya diri menjadi lebih penting dari pada hanya kemampuan intelektual siswa. dengan kepercayaan diri yang tinggi siswa akan mampu belajar untuk mencoba meskipun belum tentu langsung berhasil. Dengan keyakinan tersebut, motivasi belajar siswa meninggkat sehingga mampu meningkatkan hasil belajar siswa kelas XI Akuntansi SMK Negeri 3 Bangkalan. hasil belajar terdiri 4 kompetensi utama, yaitu kompetensi sikap spritual, sikap sosial, pengetahuan, dan keterampilan. Siswa tidak hanya mempu menguasai pengetahuan tentang akuntansi, namun juga mampu melakukan kegiatan akuntansi berbantuan komputer sehingga kemampuan yang diperoleh dari proses belajar dapat diterapkan di dunia nyata. Secara umum tujuan pembelajaran adalah sejumlah hasil belajar yang menunjukkan bahwa siswa telah melakukan aktifitas belajar yang meliputi pengetahuan, keterampilan, dan sikap (Siagian, 2012:5).

\section{KESIMPULAN}

Berdasarkan hasil dan analisis statistik yang telah diuraikan pada hasil dan pembahasan, maka peneliti menyatakan kesimpulan penelitian ini antara lain:

1. Fasilitas laboratorium komputer siswa kelas XI Akuntansi di SMKN 3 Bangkalan cukup baik

2. Penguasaan komputer siswa kelas XI Akuntansi di SMKN 3 Bangkalan cukup baik

3. Penguasaan akuntasi siswa kelas XI Akuntasi di SMK 3 Bangkalan cukup baik

4. Efikasi diri siswa kelas XI SMKN 3 Bangkalan cukup baik.

5. Pengaruh Penguasaan Komputer dan Efikasi Diri terhadap Hasil Belajar Komputer Akuntansi Accurate Siswa Kelas XI Akuntansi di SMK Negeri 3 Bangkalan

\section{DAFTAR PUSTAKA}

Alwisol. 2005. Psikologi Kepribadian. Malang : UMM Press.

Aini, P, N, dan Taman, A. 2012. Pengaruh Kemandirian Belajar Dan Lingkungan Belajar Siswa Terhadap Prestasi Belajar Akuntansi Siswa KELAS XI IPS SMA Negeri 1 Sewon Bantul Tahun Ajaran 2010/2011, Jurnal Pendidikan Akuntansi Indonesia, Volume 10 Nomor 1, halaman 48-65.

Decaprio, Richard. 2013. Tips Mengelola Laboratorium Sekolah. Jogjakarta: Diva Press.

Deswita, A, P. 2013. Pengaruh Persepsi Siswa Tentang Gaya Mengajar Guru Dan Minat Belajar Siswa Terhadap Hasil Belajar Akuntansi Pada Program Keahlian Akuntansi Siswa Kelas X Di SMKN 1 Sawahlunto, Journal of Economic dan Economic Education, Volume 2 Nomor 1, halaman 1-10.

Gie, T, L. 2004. Cara Belajar Yang Baik.Yogyakarta : Edisi kedua Gajahmada University Press.

Feist J. \& Feist Gregory J. 2010. Teori Kepribadian (Edisi Ketujuh). Jakarta: Salemba Humanika. Mariyana, dkk. 2013. Pengelolaan Lingkungan Belajar. Jakarta: KENCANA Predana Media Group.

Novalinda, E, Kantun,S, dan Widodo, J. 2017. Pengaruh Motivasi Belajar Terhadap Hasil Belajar Mata Pelajaran Akuntansi Siswa Kelas X Jurusan Akuntansi Semester Ganjil SMK PGRI 5 Jember Tahun Pelajaran 2016/2017, Jurnal Pendidikan Ekonomi, Volume 11 Nomor 2, halaman 115-119.

Purwanto, Ngalim. 2010. Psikologi Pendidikan. Bandung: PT. Remaja Rosdakarya

Siagian, S. 2015. Pengaruh Strategi Pembelajaran Dan Gaya Belajar Terhadap Hasil Belajar IPA Kelas VIII Siswa SMP Negeri 1 Dolok Panribuan, Jurnal Teknologi Pendidikan, Volume 5 Nomor 2, halaman 1-14.

Sugiyono, 2014. Metode Penelitian Kuantitatif, Kualitatif, dan R\&D, Bandung: Penerbit Alfabeta.

Susanto, Arief. 2009. Pengenalan Komputer. Diperoleh pada 20 Nopember 2018, dari Komunitas eLearning Ilmu Komputer.com.

Undang-Undang Republik Indonesia Nomor 20 Tahun 2003 tentang Sistem Pendidikan Nasional.

Wahjudi, E. 2015. Penerapan Discovery Learning Dalam Pembelajaran Ipa Sebagai Upaya Untuk Meningkatkan Hasil Belajar Siswa Kelas IX-I Di SMP Negeri 1 Kalianget, Jurnal Lensa, Volume 5 Nomor 1, halaman 1-6. 
Yuliana, A, D. 2013. Tata Kelola Pemerintahan Desa Menurut PP No 72 Tahun 2005 (studi kasus Desa Tarubasan Kecamatan Karangananom Kabubaten Klaten). Surakarta: Universitas Muhammadiyah Surakarta 